\title{
Peran Mahasiswa UIN SU Medan dalam Meningkatkan Kemampuan Calistung pada Anak Usia 5-8 Tahun di Masa Pandemi Covid-19 di Jl. Ampera I, Kelurahan Sei Sikambing Medan
}

\author{
Muhammad Fathur Rahman ${ }^{1 *}$, Rizki Nurfadillah², M. Rizky Tamimi ${ }^{3}$, Nur \\ Ainun Mardiah Rangkuti ${ }^{4}$, Fatma Yulia ${ }^{5}$ \\ ${ }^{1}$ Universitas Islam Negeri Sumatera Utara Medan, Indonesia \\ ${ }^{2}$ Universitas Islam Negeri Sumatera Utara Medan, Indonesia \\ ${ }^{3}$ Universitas Islam Negeri Sumatera Utara Medan, Indonesia \\ ${ }^{4}$ Universitas Islam Negeri Sumatera Utara Medan, Indonesia \\ ${ }^{5}$ Universitas Islam Negeri Sumatera Utara Medan, Indonesia \\ * Corresponding Author. E-mail: ${ }^{1}$ mfathurrahman@uinsu.ac.id
}

Receive: $13 / 01 / 2021$

Accepted: 23/01/2021

Published: 01/03/2021

\begin{abstract}
Abstrak
Penelitian ini bertujuan untuk dapat meningkatkan kemampuan anak usia 5-8 tahun dalam membaca, menulis dan berhitung kepada anak-anak di Jalan Ampera I, Kecamatan Sei Sikambing pada masa pandemi seperti ini. Karena pada masa ini anak-anak jarang sekali memegang buku dan pensil dikarenakan terfokusnya pada handphone atau smartphone. Kami sebagai mahasiswa mengajak masyarakat setempat untuk saling bertukar pikiran dengan menciptakan program Calistung. Menggunakan metode belajar sambil bermain membuat anak-anak di desa ini tertarik mengikuti pengajarannya. Pembelajaran yang dilakukan dengan menerapkan program kesehatan yang sangat ketat.
\end{abstract}

Kata Kunci: Anak-anak, Pendidikan, Strategi.

The Role of UIN SU Medan Students in Improving Calistung Ability in Children aged 5-8 Years in the Covid-19 Pandemic Period on Jl. Ampera I, Sei Sikambing Village, Medan

\begin{abstract}
This study aims to improve the ability of children aged 5-8 years in reading, writing and arithmetic to children on Jalan Ampera I, Sei Sikambing District during this pandemic. Because at this time children rarely hold books and pencils because the focus is on cellphones or smartphones. We as students invite the local community to exchange ideas by creating the Calistung program. Using the learning while playing method makes the children in this village interested in following his teaching. Learning is done by implementing a very strict health program.
\end{abstract}

Keywords: Children, Education, Strategy.

Pendahuluan

Kuliah Kerja Nyata (KKN) adalah salah satu di antara aktivitas perkuliahan mahasiswa diluar kelas dalam bentuk pengabdian kepada masyarakat, untuk membantu masyarakat dalam memecahkan 
permasalahan pembangunan (UINSU, 2021: 13). Mahasiswa dan masyarakat merupakan suatu hal yang saling berhubungan. Mahasiswa harus memiliki dan dapat melakukan sebuah perubahan dalam masyarakat. Dan idealnya, mahasiswa menjadi panutan dalam masyarakat, berlandaskan dengan pengetahuannya, dengan tingkat pendidikannya, norma-norma yang berlaku di sekitarnya, dan pola berfikirnya. Ide dan pemikiran cerdas seorang mahasiswa mampu mengubah paradigma yang berkembang dalam suatu kelompok dan menjadikannya terarah sesuai kepentingan bersama.

Pendidikan menjadi suatu hal yang sangat penting dan strategis, karena melalui pendidikan, generasi muda dibina dalam membangun sebuah peradaban, khususnya peradaban yang Islami dan untuk menjadi manusia yang tangguh sehingga diharapkan dapat mengangkat harkat dan martabat bangsa sesuai syariat Islam. Dalam Islam Pendidikan menjadi suatu perhatian utama. Pendidikan memiliki arti yang luas sehingga muncullah berbagai istilah tentang Pendidikan. Berbagai kosa kata bahasa arab bermunculan, salah satunya kata Tarbiyah. Tarbiyah merupakan salah satu kosa kata yang sangat baku dan popular untuk menjelaskan istilah Pendidikan itu sendiri di dalam dunia Pendidikan. Kata Tarbiyah berasal dari bahasa Arab yaitu: Rabba- YurabbiTarbiyatan, yang diartikan sebagai suatu proses atau pendampingan terhadap anak, sehingga dapat menghantarkan anak-anak tersebut kearah yang lebih baik, baik itu untuk anak sendiri maupun anak orang lain.

Calistung merupakan singkatan dari membaca, menulis dan menghitung. Membaca, menulis dan menghitung merupakan materi dasar yang harus dimiliki anak sebagai kunci untuk mendapatkan ilmu pengetahuan dan untuk mengenal lingkungan sekitarnya. Sesuai dengan firman Allah SWT. yang diturunkan kepada Nabi Muhamad SAW. sebagai wahyu pertama yakni Qur'an Surah Al- Alaq ayat :
1-5, yang memilik arti : "Bacalah dengan (menyebut) nama Tuhan-mu yang menciptakan, Dia telah menciptakan manusia dari segumpal darah, Bacalah, dan Tuhanmulah Yang Maha Mulia, Yang mengajar (manusia) dengan pena, Dia Mengajarkan manusia apa yang tidak diketahuinya". (Kemenag RI, 2014: 597). Di dalam ayat ini menjelaskan bahwa besarnya perhatian Islam dalam memerangi buta aksara, baik Arab maupun latin. Ini dikarenakan membaca merupakan tangga meuju kemuliaan dan jalan menuju ilmu pengetahuan. Malaikat Jibril mengulangi kata Iqra' (bacalah) pada ayat tersebut sebanyak tiga kali kepada Rasulullah sebagai penegasan betapa penting dan mulianya perintah membaca di dalam Islam.

Perintah membaca dan menulis ditujukan kepada seluruh umat manusia, tanpa memandang usia. Oleh sebab itu, para orangtua hendaknya mengajarkan membaca dan menulis kepada anak sejak usia dini, karena ini salah satu jalan untuk mendapatkan ilmu pengetahuan dan untuk mengenal lingkangan sekitarnya.

Membaca, menulis dan menghitung pada permulaan diarahkan kepada kegiatan bermain dibantu dengan berbagai media kreatif. Mahasiswa dituntut untuk berfikir secara kreatif dan inovatif agar anak anak tidak mudah bosan dan mau meningkatkan kemampuan belajarnya. Media yang dimasuk ialah media yang bisa membangunkan minat anak dalam belajar. Media ini biasanya terbuat dari barang barang bekas yang mudah didapat.

Ada beberapa aspek penting yang harus diketahui dalam membaca, menulis dan menghitung yaitu : (1) baca-tulis adalah perkembangan dari keterampilan membaca dan menulis maupun tindakan-tindakan kreatif dan analitis dalam memproduksi dan memahami teks; (2) perkembangan bacatulis telah dimulai sejak lama sebelum anak-anak memulai instruksi formal dalam membaca; (3) belajar baca dan tulis penting bagi keberhasilan anakanak di sekolah (Made, 2013) 
Pada masa pandemi ini banyak anak-anak warga yang lebih fokus bermain dari pada belajar. Warga Jl. Ampera I ini memberikan kesempatan kepada para mahasiswa untuk memberikan pelayanan jasa sebagai hasil untuk mengasah kemampuan. Pelayanan merupakan upaya menyenangkan orang lain dengan kemudahan - kemudahan untuk memenuhi segala kebutuhan jasa dibidang pendidikan.

Fungsi mahasiswa di dalam masyarakat yaitu sebagai agen perubahan, kontrol sosial, generasi penerus yang tangguh dan suri tauladan. Betapa pentingnya peran mahasiswa untuk membangun bangsa ini ke arah yang lebih baik. Untuk itu sebagai mahasiswa diharapkan tidak hanya sekedar belajar mencari IP setinggi-tingginya namun juga harus berkontribusi nyata di tengah-tengah masyarakat, yaitu melalui kegiatan KKN.

Terlebih di masa pandemi sekarang kontribusi dan kehadiran mahasiswa sangat dibutuhkan ditengah-tengah masyarakat di mana di harapkan dengan kegiatan $\mathrm{KKN}$ mahasiswa bisa memberikan pengajaran dan pengetahuan tentang Covid-19 yang sedang dihadapi, terkhususnya PPKM (Pemberlakuan Pembatasan Kegiatan Masyarakat) yang sudah mulai diberlakukan. Hal ini bisa direalisasikan dengan kegiatan-kegiatan mahasiswa yang sesuai dengan tema-tema yang diterapkan dalam KKN-DR UINSU yaitu Kesehatan Masyarakat dan Sosial Kemasyarakatan. Maka dari itu sangat penting terjalin hubungan kemasyarakatan yang baik diantara mahasiswa dan masyarakat khususnya di masa pandemi Covid-19.

Penelitian ini berlokasi di Jl. Ampera I Kec. Sei Sikambing, daerah ini merupakan salah satu daerah yang diberlakukannya PPKM, oleh karena itu sangat di harapkan terjalinnya hubungan kemusyawaratan mahasiswa UINSU dengan masyarakat dalam menghadapi masa PPKM Covid-19.

Masalah yang utama pada pembelajaran dimasa pandemi ini ialah kurangnya minat anak dalam membaca, menulis dan berhitung membuat para orang tua sedikit khawatir terhadap perkembangan anak. Proses pengajaran yang kurang variatif dan kreatif membuat anak - anak mudah bosan apalagi dimasa seperti ini anak - anak terpaku pada handphone (Widodo, 2017). Berdasarkan hal tersebut maka penulis membahas tentang peran mahasiswa UINSU dalam meningkatkan kemampuan baca tulis hitung anak usia di masa pandemi ini.

\section{Metode}

Penelitian ini dilakukan melalui metode pendekatan individual. Pendekatan ini dilakukan pada saat mahasiswa saling bersosialisasi kepada para warga agar mempercayakan anak-anaknya untuk diajarkan membaca, menulis, dan menghitung dengan menerapkan potokol kesehatan yang ketat.

Metode pada penelitian ini menggunakan metode penelitian kualitatif yang bertujuan untuk mengumpulkan data bersifat kualitatif yang berkaitan dengan permasalahan pembelajaran calistung. Data tersebut meliputi cara pandang, logika, konsep-konsep, pengetahuan serta masalah pada anak dalam menghadapi pembelajaran calistung. Adapun lokasi penelitian ini dilakukan di Kota Medan Jl. Ampera I, Kelurahan Sei Sikambing, Kecamatan Medan Helvetia.

Subyek dalam penelitian ini adalah anak - anak setempat yang terkait dengan pembelajaran tersebut. Adapun teknik pengumpulan data dalam penelitian kualitatif yang dilakukan adalah dengan metode observasi, dimana mahasiswa mengamati secara langsung di daerah tersebut.

\section{Hasil dan Pembahasan \\ A. Pengertian Pendidikan}

Pendidikan merupakan rangkaian proses bimbingan yang sangat penting dan sangat menentukan arah pertumbuhan dan 
perkembangan anak menuju kedewasaan. Oleh karena itu, pendidikan adalah menjadi kebutuhan dasar utama bagi setiap individu dalam proses pembinaan potensi untuk pengembangan kepribadian dan menanamkan nilai-nilai budaya.

Pendidikan anak usia dini lebih diutamakan terhadap keterampilan berbicara, bermain, beradaptasi, makan, dan menghargai orang lain. Maka dari itu, anak usia dini dikembangkan dengan cara pola belajar sambil bermain, bahkan juga bernyanyi untuk mengingat nilai-nilai dan perilaku sosial serta keagamaan.

Islam menetapkan tujuan pokok hadirnya yaitu untuk memelihara agama, jiwa, akal, jasmani, harta dan keturunan (Shihab, 1996:181). Agama merupakan kebutuhan jiwa dan aspek kehidupan manusia yang paling tinggi serta mendalam. Agama ialah mengatur dan menuntun arah kehidupan bagi setiap manusia agar mencapai keselamatan dan kebahagiaan dunia akhirat dengan seimbang (Syafaruddin, et.al., 2011: 20).

Kedudukan seorang anak dalam pendidikan Islam ialah seorang individu yang sedang tumbuh dan berkembang, baik fisik ataupun psikis dalam mencapai tujuan pendidikan melalui lembaga pendidikan.

\section{B. Strategi Pembelajaran}

Lemahnya dunia pendidikan kita adalah masalah proses pembelajaran. Dalam proses ini anak didik kurang dimotivasi untuk mengembangkan kemampuan berpikir dan berketerampilan. Untuk anak usia dini pada usia-usia tertentu tidak diberikan kesempatan untuk mengembangkan kemampuan-kemampuan yang dimiliki dirinya, baik oleh guru maupun orangtua, terlihat masih banyak anak-anak yang penakut, tidak mandiri dan tidak percaya diri. Terlebih di sekolah yang kurang inovatif dan kurang kreatif di mana banyak hal saat kegiatan dibantu oleh para guru, ketika anak didik selesai mengikuti kegiatan pendidikan pra sekolah, mereka pintar namun menjadi kurang mandiri. Undang-undang Nomor 20 Tahun 2003 tentang Sistem Pendidikan Nasional menyatakan bahwa pendidikan adalah usaha sadar dan terencana untuk mewujudkan suasana belajar dan proses pembelajaran agar peserta didik secara aktif mengembangkan potensi dirinya untuk memiliki kekuatan spiritual keagamaan, pengendalian diri kepribadian, kecerdasan akhlak mulia, serta keterampilan yang diperlukan dirinya, masyarakat, bangsa dan negara.

Berdasarkan konsep pendidikan menurut undang-undang tersebut, maka sedikitnya ada empat hal yang perlu dicermati lebih lanjut (Mutiah, 2010).

Pertama, pendidikan adalah usaha sadar yang terencana, berarti proses pendidikan di lembaga-lembaga belajar atau sekolah bukanlah proses yang dilaksanakan secara asal, tetapi proses yang bertujuan sehingga segala aktivitas belajar yang dilakukan guru dan anak didik diarahkan pada pencapaian tujuan.

Kedua, proses pendekatan yang terencana diarahkan untuk mewujudkan suasana belajar dan proses pembelajaran yang harus dimaknai oleh anak didik bahwa belajar harus memperoleh hasil dan manfaatnya yang berjalan secara seimbang untuk menempuh menjadi manusia yang berkembang secara utuh.

Ketiga, suasana pembelajaran diarahkan agar anak didik dapat mengembangkan potensi dirinya, hal ini berarti proses pendidikan harus berorientasi pada pembelajaran berpusat pada anak.

Keempat, akhir dari proses pendidikan adalah kemampuan anak untuk memiliki kekuatan spiritual keagamaan, pengendalian diri, kepribadian, kecerdasan akhlak mulia, keterampilan sosialisasi dengan masyarakat, bangsa dan negara. Dengan demikian proses pendidikan berujung pada pembentukan sikap, pengembangan kecerdasan atau intelektual, dan pengembangan keterampilan.

Permendiknas No 58 tahun 2009 tentang Standar Pendidikan Anak Usia Dini merupakan bagian integral dari Standar Nasional Pendidikan, yang dirumuskan dengan mempertimbangkan karakteristik 
penyelenggaraan PAUD dalam empat kelompok standar, yaitu (1) Standar tingkat pencapaian perkembangan; (2) Standar pendidik dan tenaga kependidikan, (3) Standar isi, proses, dan penilaian dan (4) Standar sarana dan prasarana, pengelolaan dan pembiayaan. Standar tingkat pencapaian perkembangan berisi kaidah pertumbuhan dan perkembangan anak usia dini sejak lahir sampai dengan usia 6 tahun. Tingkat pencapaian perkembangan memuat aktualisasi potensi yang dimiliki setiap anak melalui tahapan-tahapan perkembangan bukan tahapan pada akademiknya (Nuraeni, 2014: 144).

\section{Strategi pembelajaran anak usia dini}

Isjoni (2010) mengemukakan beberapa jenis strategi pembelajaran untuk PAUD, antara lain:

1. Strategi pembelajaran langsung, yaitu materi pembelajaran disajikan langsung pada anak didik dan anak didik langsung mengolahnya, misalnya bermain balok, puzzle, melukis dan lainlain. Diharapkan anak didik bekerja secara menyeluruh dan peran guru hanya sebagai fasilitator.

2. Strategi belajar individual, Dilakukan oleh anak didik secara mandiri. Kecepatan, kelambatan dan keberhasilan pembelajaran anak didik sangat ditentukan oleh masing-masing individu anak yang bersangkutan.

3. Strategi belajar kelompok, Secara beregu. Bentuk belajar kelompok bisa dalam pembelajaran kelompok besar, dan kelompok kecil. Strategi kelompok tidak memperhatikan kecepatan belajar individual karena setiap individu dianggap sama Oleh karena itu belajar kelompok dapat terjadi pada anak didik yang memiliki kemampuan tinggi akan terhambat oleh anak didik yang kemampuannya biasa-biasa saja. Strategi pembelajaran kelompok dapat dikatakan strategi pembelajaran deduktif dan induktif.

4. Strategi pembelajaran deduktif Adalah strategi pembelajaran yang dilakukan dengan mempelajari konsep-konsep, kemudian dicari kesimpulan dan ilustrasi dari yang abstrak menuju ke hal yang konkrit. Strategi ini disebut juga strategi pembelajaran dari umum ke khusus.

5. Strategi induktif, Bahan yang dipelajari dimulai dari hal-hal yang konkret kemudian secara perlahan anak didik dihadapkan pada materi yang cukup rumit, strategi ini dinamakan strategi pembelajaran dari khusus ke umum.

Berdasarkan hasil analisis kami dengan para orang tua siswa di Jl. Ampera I Kelurahan Seikambing Kecamatan Medan Helvetia ini diambil kesimpulan bahwa sebagian besar dari orangtua siswa menjelaskan pembelajaran calistung murni diberikan pada siswa tersebut sebagai persiapan melanjutkan ke sekolah dasar. Pembelajaran ini dilakukan agar siswa lebih terampil dalam calistung lebih baik lagi, banyak orangtua yang tak acuh pada tahap kepekaan siswa dalam calistung untuk mengembangkan kecerdasan siswa tersebut.

Calistung pada anak dilingkungan penelitian juga sudah sangat baik dikarenakan orangtua mengajarkan anak tersebut di rumah. Serta saat peneliti melakukan KKN-DR juga membuka pembelajaran calistung serta mengaji untuk anak sekitar agar wawasan mereka lebih maju lagi dan tidak lupa saat pembelajaran Daring saat ini

Anak pada usia lahir sampai dengan pendidikan dasar merupakan "masa emas" dalam tahapan kehidupan yang akan menentukan perkembangan selanjutnya. Karena pada masa usia tersebut anak masih sangat rentan pemikirannya apabila penanganan dilakukan terhadap siswa tersebut tidak tepat maka hal tersebut akan merugikan anak itu sendiri dan akan berakibat kurang baik bagi kehidupannya.

Proses belajar menuju kemampuan balistung pada anak sebaiknya tidak dilakukan dengan pendekatan yang formal, karena dikhawatirkan akan membuat anak tersebut merasa tertekan dan jenuh, mengingat kemampuan anak itu dapat berkonsentrasi pada suatu topik bahasan 
yang biasanya masih terbatas dan secara umum pada pendidikan TK anak masih berada dalam dunianya yaitu bermain. Apalagi bila dalam memberi pelajaran tersebut dilakukan dengan kekerasan, misalnya pembelajaran diberikan dengan teriakan atau bentakan yang mana anak belum mampu mengikuti pelajaran calistung yang diberikan, maka itu bisa menghambat perkembangan kemampuan berfikirnya secara optimal.

Orangtua anak sekitaran penelitian juga mengatakan sekarang untuk Ujian Masuk Sekolah Dasar dilakukan dengan menggunakan tes balistung anak tersebut. Dalam ujian tersebut juga lebih bersifat santai untuk mengajak murid sambil tertawa. Hal ini dilakukan agar calon siswa tidak terkesan seperti sedang ujian sehingga anak tersebut tidak takut pada saat ujian berlangsung.

Kegiatan ini dilaksanakan selama sebulan di Jl. Ampera I Kelurahan SeiKambing Kecamatan Helvetia kegiatan ini diikuti oleh beberapa anak-anak warga. Adapun kegiatan yang dilakukan adalah pemberian dan memperkenalkan materi yang bersifat konseptual tentang baca tulis dan menghitung.

Berdasarkan permasalahan yang ditemui anak -anak pada daerah tersebut kurang dalam belajar mengajar dikarenakan ini masa pandemi sehingga membuat mereka belajar mandiri. Kegiatan diawali dengan memberikan sosialisai kepada warga sekitar tentang maksud hadirnya mahasiswa kkn ke daerah tersebut.

Mengenai masalah kegiatan mahasiswa memberikan pengajaran dengan media-media kreatif sperti membuat celengan dari botol bekas dengan maksud tujuan menciptakan sensor motorik kepada anak - anak. Mahasiswa juga mengajarkan baca tulis dengan bernyanyi bersama mendisiplikan diri. Pada setiap pertemuan anak - anak akan diberikan hadiah atas pencapaian yang telah didapat sehingga anak - anak tertarik untuk terus belajar.

Hasil yang dicapai dalam kegiatan ini melahirkan hasil yang positif. Partisipasi anak - anak dalam pembelajaran baca tulis hitung dengan metode bernyanyi bersama dan pemberian hadiah meningkat pesat. Karena dalam kegiatan pembelajaran baik fisik maupun mental, mental dan fisik (Santyasa, 2009). Hal utama yang dapat dilihat dalam pembelajaran adalah partisipasi siswa dalam pembelajaran (Yoshida, 2016).

Dengan demikian, program ini menekankan bagaimana cara mengajar dengan melihat kelebihan dan kekurangannya, yang tidak hanya memperkuat praktik pembelajaran di kemudian hari, tetapi juga hasil dari pelaksanaan kegiatan pendidikan siswa.

\section{Simpulan}

Berdasarkan hasil kegiatan dan pembahasan program kegiatan ini, dapat disimpulkan bahwa: kegiatan pembelajaran ini sangat membantu meningkatkan pengetahuan anak baik secara jasmani dan rohani hasil yang kami dapat setelah mengajari anak anak tersebut adalah miris sekali melihat kondisi mereka karena sudah 2 tahun lamanya belajar dirumah,banyak anak yang bahkan sulit untuk membaca hal ini dikarenakan kurangnya arahan dari orangtua terkait pembelajaran daring yang semestinya harus di bimbing oleh orangtua dan guru,melalui pembelajaran yang kami bawa sedikit membantu anak anak untuk dapat berinteraksi dengan baik dan juga mengembangkan kreatifitasnya dengan begitu pula mereka dapat mengembangkan skill mereka mulai sedari kecil pembelajaran yang kami berikan kepada anak anak bertujuan untuk memberikan pengarahan bahwa sebenarnya belajar sambil bermain sangatlah menyenangkan dengan begitu anak-anak tidak akan cepat merasa bosan dengan pembelajaran tersebut. 
Jurnal Edumaspul, 5 (1), Year 2021 - 736

(Muhammad Fathur Rahman, Rizki Nurfadillah, M. Rizky Tamimi, Nur Ainun Mardiah Rangkuti, Fatma Yulia)

Kami berharap pandemi ini cepat berakhir agar anak anak yang masi usia dini dapat segera merasakan pembelajaran tatap muka yang biasanya dilakukan dan kami juga mengharapkan agar para orangtua untuk dapat semerta merta memperhatikan kondisi anaknya agar anaknya dapat belajar dengan baik dan benar.

\section{Daftar Pustaka}

[1] Isjoni. (2010). Model Pembelajaran Anak Usia Dini. Bandung: Alfabeta.

[2] Made, N. G. (2013). Peningkatan Kemampuan Baca Tulis Permulaan. Jurnal Pendidikan Anak Usia Dini. http://journal.unj.ac.id/unj/index.php/i pud/article/download/3870/2889.

[3] Nuraeni. (2014). Strategi Pembelajaran untuk Anak Usia Dini. Prisma Sains:
Jurnal Pengkajian IImu Pembelajaran Matematika dan IPA, 2(1). https://ejournal.undikma.ac.id/index.php/prisma sains/article/view/1069.

[4] Santyasa. (2009). Implementasi Lesson Study. Singaraja: Universitas Pendidikan Ganesha.

[5] Syafaruddin, et.al. (2011). Pendidikan Prasekolah: Perspektif Pendidikan Islam dan Umum. Medan: Perdana Publishing.

[6] Widodo. (2017). Aplikasi Pembelajaran Baca, Tulis, Hitung (Calistung) sebagai Alat Bantu Ajar untuk Anak TK Berbasis Multimedia. Jurnal Teknologi Informasi. http://ojs.ustj.ac.id/jti/article/view/227.

[7] Yoshida. (2016). Lesson Study: An Introduction. Tokyo: Global Education Resource.. 